\title{
Biotransformation and oxidative stress responses in fish (Astyanax aeneus) inhabiting a Caribbean estuary contaminated with pesticide residues from agricultural runoff
}

Freylan Mena ( $\nabla$ fmena@una.cr)

Universidad Nacional de Costa Rica https://orcid.org/0000-0002-1215-0378

\section{Seiling Vargas}

Universidad Nacional de Costa Rica

Meyer Guevara-Mora

Universidad Nacional de Costa Rica

\section{J. Mauro Vargas-Hernández}

Universidad Nacional de Costa Rica

Clemens Ruepert

Universidad Nacional de Costa Rica

\section{Research Article}

Keywords: Pesticides, Biomarkers, Tropical estuary, Biotransformation, Oxidative stress, Astyanax aeneus

Posted Date: January 10th, 2022

DOI: https://doi.org/10.21203/rs.3.rs-1160641/v1

License: (c) (1) This work is licensed under a Creative Commons Attribution 4.0 International License.

Read Full License 


\section{Abstract}

The estuarine ecosystem of Laguna Madre de Dios (LMD), in the Caribbean coast of Costa Rica, is exposed to contamination with pesticide residues coming from the upstream agricultural areas. Biomarkers can provide a better indication of the fitness of biota in real mixture exposure scenarios than traditional lethal dose toxicity measurements. Here, we measured biomarkers of biotransformation, oxidative stress and neurotoxicity on Astyanax aeneus, an abundant fish species in LMD. Glutathione Stransferase activity (GST), catalase activity (CAT), lipid peroxidation (LPO), and cholinesterase activity (ChE) were measured in fish collected during seven sampling campaigns, carried out between 2016 and 2018. Pesticide residues were analysed in surface water samples collected every time fish were sampled. Residues of 25 pesticides, including fungicides, insecticides and herbicides, were detected. The biomarkers measured in $A$. aeneus varied along the sampling moments, however, biotransformation and oxidative stress signals showed coupled responses throughout the assessment. Furthermore, significant correlations were established between three biomarkers (GST, LPO and CAT) and individual pesticides, as well as between GST and LPO with groups of pesticides with shared biocide action. Among pesticides, insecticide residues had a major influence on the responses observed in fish. This work shows that the frequent exposure to environmentally relevant concentrations of pesticides can be related to physiological responses in fish that affect their health. This early warning information should be considered to improve the protection of estuarine ecosystems in the tropics.

\section{Introduction}

The Laguna Madre de Dios (LMD) estuary is located in the Caribbean coast of Costa Rica. Inflows include the Madre de Dios river, along with the Pacuare and Chirripó catchments. All the three watersheds, but mainly Madre de Dios, sustain areas of intensive agriculture, dominated by banana plantations, with pineapple and rice being produced as well in the area. Pesticide use is high in these crops, especially in banana (76 kg*ha-1*yr-1) and pineapple (47 kg*ha-1*yr-1) (Echeverría-Sáenz et al. 2018). Further, the humid and rainy climate of the region, with about $4500 \mathrm{~mm} /$ year (IMN, 2021), flushes pesticide residues from croplands into surrounding tributaries of LMD.

Estuaries are productive, diverse yet fragile ecosystems that throughout the world have been suffering deterioration caused by human activities (Barbier et al. 2011; Jennerjahn and Mitchell 2013; Warwick et al. 2018) and present particular characteristics regarding the environmental behaviour of chemical pollutants as well as the effects that they can cause to estuarine biota (Schlenk and Lavado 2011; Cuevas et al. 2018). In the case of the Madre de Dios river and coastal lagoon, pesticide residues have been detected in surface water for many years (Mena et al. 2014; Diepens et al. 2014; Arias-Andrés et al. 2018). Meanwhile, a retrospective assessment of ecological risk, estimated with data from regular surface water sampling, demonstrated that the constant presence of pesticide residues in the system represents a high risk for its biota, mainly for primary producers and aquatic arthropods (Rämö et al. 2018). In this regard, changes in macroinvertebrate communities related to pesticide pollution have already been observed in the water catchment (Echeverría-Sáenz et al. 2018). 
Historically, one of the most worrying pieces of evidence of the degradation in the LMD system is the frequent occurrence of massive fish die-offs (La Nación 2009; ElPaís.cr 2017). However, the incidence of these events has not been clearly related to the concentrations of pesticide residues commonly found in the environment (Polidoro and Morra 2016). On the contrary, according to chemical assessment, the concentrations of pesticide residues detected most of the times in the surface water of the system, are below the expected to cause acute effects to fish (Arias-Andrés et al. 2018; Rämö et al. 2018). Under this scenario, pulse events related to runoff caused by heavy rains might explain massive die-offs, however, those cases are not properly characterized yet. Further, it would be relevant to know if the constant exposure to environmental concentrations of pesticides, individually or in mixtures, causes negative effects on fish.

The exposure of an organism to pesticides can induce biochemical responses related to biotransformation, like the activation of enzymes of the Glutathione S-transferase family (GST) that catalyse conjugation reactions in phase II of the process (Schlenk et al. 2008). As well, the oxidation reactions from phase I of biotransformation are linked to the liberation of reactive oxygen species that cause oxidative stress and can lead to cellular damage, like lipid peroxidation (LPO) in the cell membranes (Narra et al. 2017). As a response to oxidative stress, the cells activate antioxidant defences with the participation of enzymes like catalase (CAT) which breaks down the hydrogen peroxide (Martínez-Álvarez et al. 2005; Schlenk et al. 2008). These biotransformation and oxidative stress are complex, yet unspecific processes that can be elicited by several xeno and endobiotics (Schlenk et al. 2008). Some compounds have more specific cellular targets and are related to specific effects on the organism. This is the case of chemicals like organophosphate and carbamate insecticides, which cause neurotoxicity by inhibiting the cholinesterase (ChE) activity in the nervous system (Colovic et al. 2013). All these types of sub-lethal responses are valuable as biomarkers as they can be triggered in fish, by exposure to environmentally relevant concentrations of pesticides (Karmakar et al. 2016; SandovalHerrera et al. 2019). In the case of LMD, where the presence of residues of several pesticides are regularly present in water, it is expected that fish would show biotransformation and oxidative stress responses. As well, cholinesterase inhibition would be expected and related to the presence of organophosphates and carbamates in the environment.

In Costa Rica, and even in more developed countries, the risks that pesticides represent for the ecosystems is estimated mainly based on the acute toxicity of individual substances (La Gaceta 2007; EFSA 2013) but this approach is intensively questioned at the present (Brühl and Zaller 2019; Topping et al. 2020). In a real scenario, ecosystems are exposed to mixtures of substances and most of the time, in concentrations not expected to cause acute toxicity (de Souza Machado et al. 2019; Schreiner et al. 2016). This level of pollution in the environment might not be lethal for fish populations, but the constant exposure might trigger physiological responses that can affect the fitness of organisms regarding essential processes like growth, reproduction, and predation avoidance (Floyd et al. 2008; SandovalHerrera et al. 2019). 
The fish, Astyanax aeneus, has been used for previous ecotoxicological studies carried out in Costa Rica (Mena et al. 2014; Sandoval-Herrera et al. 2019). This characin is the most abundant fish species in LMD and one of the most broadly distributed species in Costa Rica, ranging from brackish water at sea level to creeks until 1000 meters above sea level and tolerating temperatures from 20 to $37^{\circ} \mathrm{C}$ (Bussing 2002).

Considering the ecological value and vulnerability of LMD and the amount of evidence regarding the prevalent contamination of this estuary with pesticides residues, this study aimed to evaluate if the exposure of resident $A$. aeneus to such conditions, would cause biochemical responses that might translate into physiological effects that compromise their population. As well, we mean to provide evidence that the standard toxicological endpoints are not always adequate to protect fish and likely other species in contaminated ecosystems.

\section{Material And Methods}

Data presented here corresponds to seven sampling campaigns, carried out between 2016 and 2018 in LMD, covering periods of higher and lower precipitation in the region. We originally planned to capture the fish at four points of the estuary, including the three main inflows and the centre of the lagoon, and correlate the biomarkers with pesticides analysed for the water sample of each point. However, after preliminary samplings and an analysis of the fish distribution along the estuary, we decided to sample the lagoon as a unit. Thus, fish were captured at seven points distributed along the margins of the lagoon, while keeping the collection of water samples at the four points located at main inflows (Pacuare river, Santa Marta channel and Madre de Dios river) and the centre of the estuary (Fig. 1).

A total of $173 \mathrm{fish}$, both sexes, standard length range: 3.3 to $11.7 \mathrm{~cm}$; average $7.9 \pm 1.24 \mathrm{~cm}$ were captured and analysed during the project. A maximum of 30 fish, were collected every sampling, from the whole extension of $L M D$, using seven points distributed along the margins and tributaries of the lagoon (Fig. 1). Fish were captured using a cast net of $1.8 \mathrm{~m}$ radius and $2.5 \mathrm{~cm}$ mesh. After collection, fish were measured and immediately sacrificed by decapitation. Then, samples of brain, liver and dorsal muscle were taken (in the case of liver and brain, the whole organ was collected, in the case of muscle, approximately $50 \mathrm{mg}$ of dorsal tissue were taken). Each sample was placed in a $1.5 \mathrm{ml}$ microtube and immediately frozen with liquid nitrogen. Samples were transported in liquid nitrogen to the laboratory of ecotoxicology at IRET (ECOTOX) where they were preserved at $-80^{\circ} \mathrm{C}$ until the biomarkers were measured.

\subsection{Biomarker analyses:}

For biochemical analyses, samples were homogenized in appropriate phosphate $\left(\mathrm{K}_{2} \mathrm{HPO}_{4} / \mathrm{KH}_{2} \mathrm{PO}_{4}\right)$ buffers: buffer $100 \mathrm{mM}$ with pH 7.2 for brain and muscle samples and $100 \mathrm{mM}$ with pH 7.4 for liver samples. A Branson ${ }^{\circledR}$ SLPt sonicator was used for sample homogenization. After homogenization, muscle and brain samples were centrifuged at $10600 \mathrm{rcf}, 4^{\circ} \mathrm{C}$ for $5 \mathrm{~min}$. and the supernatant was used for ChE analyses. In the case of liver samples, an aliquot of the homogenate was separated immediately after homogenization and mixed with $0.2 \mathrm{mM}$ butylated hydroxytoluene (BHT) for the LPO analysis; then, 
the rest of the homogenate was centrifuged at $15300 \mathrm{rcf}, 4^{\circ} \mathrm{C}$ for $20 \mathrm{~min}$. and the supernatant was used for GST and CAT analyses. All biomarker responses were normalized by protein content. For this, protein concentration was measured in each sample with the Bradford method (1976), using a kit from BioRad® with bovine serum albumin as a protein standard.

Cholinesterase (ChE) activity in muscle and brain samples was measured according to the method of Ellman et al. (1961), adapted to microplate by Guilhermino et al. (1996). Briefly, samples were exposed to a reaction mixture containing the synthetic substrate, acetylthiocholine $(1 \mathrm{mM})$ and the conjugate 5,5'dithiobis(2-nitrobenzoic acid) (DTNB) $(0.1 \mathrm{mM})$; the reaction was measured at $415 \mathrm{~nm}$ for $10 \mathrm{~min}$ and expressed as nanomoles of substrate metabolized per minute per milligram of protein. Glutathione Stransferase (GST) activity was measured according to Habig et al. (1974), exposing samples to a mixture containing $1 \mathrm{mM}$ of 1 -chloro-2,4-dinitrobenzene (CDNB), and $1 \mathrm{mM}$ of reduced glutathione (GSH). The reaction was monitored at $340 \mathrm{~nm}$ for $3 \mathrm{~min}$; activity was reported as nanomoles per minute per milligram of protein. Lipid peroxidation (LPO) was measured by the thiobarbituric acid reactive species (TBARS) assay (Oakes and Van der Kraak 2003) and expressed as nanomoles of TBARS per milligram of protein. Catalase (CAT) activity was measured according to the method of Aebi (1974) as the decrease in absorbance at $240 \mathrm{~nm}$ due to $\mathrm{H}_{2} \mathrm{O}_{2}$ consumption. The reaction was followed for 20 seconds and expressed as micromoles of substrate metabolized per minute per milligram of protein. The integrated biomarker response (IBR) was calculated according to Devin et al. (2014). Circular permutations in the order of the biomarkers were performed during the calculation to produce a set of IBR values for each sample and be able to compare sites.

\subsection{Chemical analyses:}

Pesticide residues were measured in surface water samples collected at four points of the lagoon, covering the three main inflows and the centre of the estuary (red points in Fig. 1). Seven field trips were carried out along the 2016-2018 period, with a total of 28 samples analysed. The samples were extracted by solid phase, using Isolute ENV+ $200 \mathrm{mg}$ cartridges (Biotage). The analytical techniques used for the identification and quantification of pesticide residues were: gas chromatography with mass detector (Agilent 7890A/5975C) and liquid chromatography coupled to a triple-quadrupole mass spectrometer (Waters ACQUITY UPLC H-Class with a TQ-S micro MS). When a substance was detected but it was below the limit of quantification (LOQ), its concentration was estimated as half of that LOQ.

Physical-chemical parameters were measured at every point where water samples were collected. Median values were used for analyses. A calibrated $\mathrm{Hach}{ }^{\circledR}, \mathrm{HQ} 40 \mathrm{~d}$ multi-probe was used to record $\mathrm{pH}$, temperature $\left({ }^{\circ} \mathrm{C}\right)$, conductivity $(\mu \mathrm{S} / \mathrm{cm})$ and dissolved oxygen $(\mathrm{DO}, \mathrm{mg} / \mathrm{L})$.

Four water samples were taken every sampling campaign, to work with the worst scenario, when a substance was detected in more than one sample, the maximum concentration measured among them was considered for the correlation analyses with fish biomarkers. Also, pesticides were grouped on the criteria of biocide action and the correlation of these groups with the biomarker responses was tested. For this, four groups were considered: herbicides ( $\mathrm{n}$ herb and $\mu \mathrm{g}$ herb), fungicides ( $\mathrm{n}$ fung and $\mu \mathrm{g}$ fung), 
insecticides ( $\mathrm{n}$ insect and $\mu \mathrm{g}$ insect) and because of the use of ChE as a biomarker, organophosphates (OP) and carbamates were grouped (n OP-Carb and $\mu$ g OP-Carb). In each case, " $n$ " represents the number of substances within that group, detected in LMD for that sampling campaign and " $\mu \mathrm{g}$ " represents the summed amount, in $\mu \mathrm{g} / \mathrm{L}$, of the maximum concentrations of the substances in that group, for that campaign.

\subsection{Statistical analyses:}

All analyses were carried out using R 3.6.1 (R Core Team 2019). Biomarker data were analysed for normality (Shapiro test, $p<0.05$ ). As the data for four out of five biomarkers did not meet a normal distribution, a non-parametric test (Kruskal-Wallis, $p<0.05$ ) followed by the post-hoc pairwise Wilcoxon rank sum test were applied to compare the biomarker responses and identify differences in their responses among sampling campaigns. The relationship between the maximum concentrations of pesticides (individually and grouped), as well as the number of compounds per sample, detected during each sampling moment and the biomarkers measured in the sample of $A$. aeneus was tested with a Spearman correlation (rho), using the Hmisc package (Harrell 2020). Before any comparisons of biomarkers responses among sampling moments and correlation between the biomarkers and pesticide residues were done, the effect of size and sex of the fish on the biomarker responses were assessed. The effect of sex was evaluated with a Wilcoxon test $(<0.05)$ and differences were found for ChEm [higher in males $(p=2 e-4)$ ] and CAT [higher in males $(p=4 e-5)$ ]. Effect of size was evaluated with a spearman correlation (rho) and muscle ChE ( $p=8 \mathrm{e}-13)$ as well as brain $\mathrm{ChE}(\mathrm{p}=1 \mathrm{e}-2)$ had negative correlation with size. Meanwhile, no influence of sex or size was observed for LPO and GST. For this reason, data for those biomarkers affected by size or sex were analysed differently: In the case of catalase, comparisons and correlations were tested by sex. In the case of brain ChE, the data was divided into size categories and the extremes of size were removed, then, the comparisons and correlations were tested with a subsample which's size did not correlate with size $(n=103)$. Finally, as the correlation of muscle ChE with size was significant for any size category, this biomarker was removed from the analyses. We suggest muscle $\mathrm{ChE}$ is not a good biomarker in fish for field studies where the size of the animals varies. We include a figure (Online resource 1) to show the strong negative correlation of this biomarker with the size of the fish.

The pesticide residues matrix composition throughout LMD sampling points and field trips was evaluated with a PERMANOVA analysis, using the adonis, vegan 2.5.7 package (Oksanen 2011); a presence/absence data transformation was applied to reduce the influence of common pesticides residues in the water samples.

\section{Results}

The physical-chemical parameters recorded during the assessment were in the acceptable range, according to the distribution of the species described by Bussing (2002) (Table 1). Temperature varied between 24.3 and $32.4^{\circ} \mathrm{C}$; pH between 6.1 and 8 . The higher variations were observed in the DO, between 3.5 and $11 \mathrm{mg} / \mathrm{L}$; and conductivity, between 182 and $832 \mu \mathrm{S} / \mathrm{cm}$. In the last case, probably related to the 
changes in salinity of the estuary. Two environmental parameters, $\mathrm{DO}$ and $\mathrm{pH}$, had significant correlations with biomarkers measured in $A$. aeneus, find details onward in this section.

Table 1

Physical-chemical parameters recorded at LMD for every sampling moment. Data are medians (range) from four measurements recorded every time.

\begin{tabular}{|lllll|}
\hline Sampling & Temperature $\left({ }^{\circ} \mathrm{C}\right)$ & $\mathrm{pH}$ & Conductivity $(\mu \mathrm{S} / \mathrm{cm})$ & $\mathrm{DO}(\mathrm{mg} / \mathrm{L})$ \\
\hline may-16 & $30.5(28.5-31.1)$ & $7.9(7.6-8.0)$ & $832(176-064)$ & $9.5(7.3-9.7)$ \\
\hline jul-16 & $27.5(26.2-29.4)$ & $6.4(6.1-6.6)$ & $182(156-615)$ & $5.1(3,8-6)$ \\
\hline oct-16 & $30.5(26.9-32.4)$ & $7.3(7.1-7.5)$ & $233(121-305)$ & $4.7(3.5-7)$ \\
\hline dec-16 & $27.2(24.3-28.1)$ & $7.4(7.2-7.4)$ & $190(128-203)$ & $8.9(8.2-10.3)$ \\
\hline feb-17 & $29.3(27-30.5)$ & $6.9(6,8-6,9)$ & $440(230-490)$ & $9.3(7.3-11)$ \\
\hline sep-17 & $29.4(27.8-30.1)$ & $7.7(7.4-7.8)$ & $240(154-270)$ & $8.0(7.4-10.5)$ \\
\hline feb-18 & $25.6(24.7-26,4)$ & $7.5(7.3-7.7)$ & $518(181-728)$ & $6.5(4.6-7.5)$ \\
\hline
\end{tabular}

Thirty-seven pesticides were analysed in the water samples, based on their use on the crops upstream from LMD. A total of 25 pesticides were detected in the lagoon during the research period: 15 fungicides, 6 insecticides and 4 herbicides (Table 2). Four substances, the insecticide buprofezin, the herbicide ametryn and the fungicides azoxystrobin and pyrimethanil, were detected in every sampling campaign. The least number of substances, eight, was recorded in May-2016; eleven substances registered in Jul2016 and Dec-2016, fifteen in Feb-2017, sixteen in Oct-2016 and Feb-2017; while the higher number, nineteen, was registered in Feb-2018. Comparing the maximum concentrations registered during this assessment to reference toxicity values, none of the substances detected in the lagoon, individually, was expected to cause acute nor chronic effects on fish (Table 2).

According to PERMANOVA analyses, the pesticides presence/absence matrix shows statistical differences between sampling times $(F 6,19=10.024 ; r 2=0.76 ; p=0.001)$ but not between sampling sites for a given sampling moment $(F 4,21=0.62 ; r 2=0.11 ; p=0.846)$ 
Table 2

Pesticide residues detected along seven surface water samplings of Laguna Madre de Dios (LMD). Points (O) indicate that the substance was detected in the corresponding sampling moment in LMD. Maximum (peak) concentration measured for each substance during the assessment, as well as reference toxicity values (acute and chronic) of each compound to fish, are included.

\begin{tabular}{|c|c|c|c|c|c|c|c|c|c|c|}
\hline \multirow[t]{2}{*}{ Pesticide } & \multicolumn{7}{|c|}{ Sampling campaign (month-year) } & \multirow{2}{*}{$\begin{array}{l}\text { peak } \\
(\mu \mathrm{g} / \mathrm{L})\end{array}$} & \multirow{2}{*}{$\begin{array}{l}{ }^{\mathrm{b}} \mathrm{Ref} \\
\mathrm{LC}_{50} \\
(\mu \mathrm{g} / \mathrm{L})\end{array}$} & \multirow{2}{*}{$\begin{array}{l}{ }^{{ }^{2}}{ }^{2}{ }^{2} \\
\mathrm{EC}_{50} \\
\text { Chronic } \\
(\mu \mathrm{g} / \mathrm{L})\end{array}$} \\
\hline & $\begin{array}{l}\text { May- } \\
16\end{array}$ & $\begin{array}{l}\text { Jul- } \\
16\end{array}$ & $\begin{array}{l}\text { Oct- } \\
16\end{array}$ & $\begin{array}{l}\text { Dec- } \\
16\end{array}$ & $\begin{array}{l}\text { Feb- } \\
17\end{array}$ & $\begin{array}{l}\text { Sep- } \\
17\end{array}$ & $\begin{array}{l}\text { Feb- } \\
18\end{array}$ & & & \\
\hline ametryn & 0 & 0 & 0 & 0 & 0 & 0 & 0 & 0.46 & 5000 & 700 \\
\hline azoxystrobin & 0 & 0 & 0 & 0 & 0 & 0 & 0 & 1.11 & 470 & 147 \\
\hline boscalid & & & & & 0 & 0 & 0 & 0.3 & 2700 & 125 \\
\hline bromacil & & & & 0 & & & & 0.08 & 36000 & 96500 \\
\hline buprofezin & 0 & 0 & 0 & 0 & 0 & 0 & 0 & 0.12 & 330 & 52 \\
\hline carbaryl & & & 0 & & & & 0 & 0.05 & 2600 & 210 \\
\hline chlorothalonil & & & 0 & 0 & & & & 0.01 & 17 & 1.4 \\
\hline chlorpyrifos & & 0 & & 0 & & & 0 & 0.03 & 25 & 0.14 \\
\hline diazinon & & 0 & 0 & 0 & & 0 & 0 & 0.3 & 3100 & 700 \\
\hline difenoconazole & & & & 0 & 0 & & 0 & 0.5 & 1100 & 23 \\
\hline diuron & 0 & & 0 & & 0 & 0 & 0 & 0.41 & 6700 & 410 \\
\hline epoxiconazole & & 0 & 0 & 0 & 0 & 0 & 0 & 0.4 & 3140 & 10 \\
\hline ethoprophos & & 0 & 0 & & 0 & 0 & & 0.6 & 320 & 64 \\
\hline fenamiphos & & & 0 & & & & 0 & 0.15 & 9,3 & 3.8 \\
\hline fenpropimorph & & & 0 & & 0 & 0 & 0 & 0.03 & 2300 & 100 \\
\hline fluopyram & & & 0 & & 0 & 0 & 0 & 0.39 & 980 & 135 \\
\hline hexazinone & & 0 & 0 & 0 & 0 & 0 & & 0.33 & 320000 & 85.5 \\
\hline metalaxyl & 0 & & & & 0 & 0 & 0 & 0.05 & 960 & - \\
\hline myclobutanil & 0 & 0 & & & 0 & 0 & 0 & 0.13 & 2000 & 200 \\
\hline propiconazole & & & & & & & 0 & 0.03 & 2600 & 68 \\
\hline pyrimethanil & 0 & 0 & 0 & 0 & 0 & 0 & ○ & 0.13 & 10560 & 1600 \\
\hline tebuconazole & & & 0 & & & & & 0.15 & 4400 & 10 \\
\hline
\end{tabular}




\begin{tabular}{|c|c|c|c|c|c|c|c|c|}
\hline Pesticide & Sar & paic & ear) & & & $\begin{array}{l}\text { peak } \\
(\mu \mathrm{g} / \mathrm{L})\end{array}$ & $\begin{array}{l}{ }^{{ }^{2}} \text { Ref } \\
\mathrm{LC}_{50} \\
(\mu \mathrm{g} / \mathrm{L})\end{array}$ & $\begin{array}{l}{ }^{b_{R e f}} \\
\text { EC }_{50} \\
\text { Chronic } \\
(\mu \mathrm{g} / \mathrm{L})\end{array}$ \\
\hline thiabendazole & 0 & 0 & 0 & 0 & 0 & 0.72 & 550 & 12 \\
\hline triadimenol & & & & & 0 & 0.18 & 21300 & 3130 \\
\hline triadimefon & & & & & & 0.2 & 4080 & 17 \\
\hline
\end{tabular}

${ }^{b}$ Reference acute and chronic toxicity values for different fish species, as retrieved from the Pesticides Properties DataBase (PPDB) (Lewis et al. 2016).

Biomarker's responses in fish varied during the evaluated period (Fig. 2). Regarding brain ChE activity, the lower levels were observed in Dec-2016 and Sep-2017. (Fig. 2. A). Consistency was observed regarding the response of biotransformation and oxidative stress biomarkers: higher levels of GST, LPO and CAT were measured in fish collected in the periods of Jul-2016 and Oct-2016, while the lower level of response in these three markers occurred in the sample collected during May-2016 (Fig. 2. B, C, D). There was no coincidence in the response of the neurotoxic biomarker regarding the biotransformation and oxidative stress signals. It was interesting, in the case of catalase, that even as the response of the biomarker differed among males and females, the response of both sexes was similar in most cases, especially at the moments of lower and higher responses (Fig. 2. C). The IBR showed higher responses of biomarkers together in Jul-2016 and Oct-2016; while, consistent with individual biomarkers, the lower response was estimated in May-2016 (Fig. 2. E).

Water samples were taken at four points of the lagoon (Fig. 1) every time a sample of fish was collected. The higher concentration of each substance measured per sampling moment was used to test correlations with the measured response of the biomarkers. Some of the pesticides found in the lagoon had significant correlations with the biomarkers measured in A. aeneus. the OP, ethoprophos, was positively correlated with the induction of GST, a biomarker related with biotransformation phase Il; meanwhile, diazinon (OP) and the chitin synthesis inhibitor, buprofezin, were correlated with signs of oxidative stress (LPO) (Fig. 3. A). LPO was negatively correlated with the fungicides metalaxyl and azoxystrobin and the later compound had a negative correlation with CAT in males, as well. Aside from the pesticides, DO correlated negatively with LPO and the IBR, while pH had a negative correlation with CAT in both sexes. The IBR showed significant positive correlations with GST and CAT in females. Regarding IBR, its magnitude was also positively correlated with diazinon (Fig. 3A).

When the pesticide residues were considered by groups (OP-carbamate or by biocide action), we found positive correlations between the amounts of insecticides and the amount of OP-carbamates present in the water with the induction of GST and the IBR. As well, the number of OP-carbamates present was positively correlated with LPO (Fig. 3. B). Interestingly, no significant correlation was observed between 
the presence of OP and carbamates, individually or grouped, with lower levels of brain ChE activity in $A$. aeneus, as it would be expected because of their modes of action.

\section{Discussion}

Estuaries are dynamic ecosystems with variations in temperature, salinity and dissolved oxygen changing rapidly. The communities have become established in such habitats, with organisms adapted to this natural stress (Elliott and Quintino 2007). However, the species inhabiting these ecosystems can be very sensitive to anthropogenic stressors (Monserrat et al. 2007; Jennerjahn and Mitchell 2013; Toft et al. 2018; Barletta and Lima 2019). The pollution of estuaries with sub-lethal concentrations of chemical contaminants, including pesticides, can affect the physiology of resident fish and these alterations can translate into effects on higher levels of biological organization (Ferreira et al. 2005; Baldwin et al. 2009).

The description of the hydrography in LMD estuary is incipient. The data currently available (not included here) indicates that the lagoon is highly dominated by sea water and has vertical stratification in temperature and salinity during periods of low-water discharges from rivers (March - April). Conversely, the lagoon is highly dominated by fresh water during periods of high-water discharges from rivers (October - December), during this period seawater flows into the lagoon only during spring tides and more vertical mixing takes place. Besides, part of the colder waters from Pacuare river tends to flow upstream into the lagoon just underneath the lighter and warmer waters from Madre de Dios river and Santa Martha Channel which flow seaward; the other part of the water discharge from Pacuare river flows directly to the sea just above the denser sea-water inflow moving to the lagoon at the bottom level. The flow from the Pacuare river has such as strong momentum that neither flows from the sea nor the lagoon can penetrate to the Pacuare basin.

This complex hydrodynamics and the bathymetry create horizontal gradients of salinity across the lagoon at the subsurface level, particularly during low-water discharges from rivers when the salt-wedge can penetrate long distances into the lagoon. At the surface level there are no appreciable horizontal gradients in salinity; however, the encounter of fresh-water masses of different temperatures can occur near the surface, particularly when warmer waters from Madre de Dios river meet the colder waters from the Pacuare river. A deeper explanation of the hydrodynamics of LMD is out of the scope of this work and it will be addressed in a separate manuscript still under preparation.

Considering the above description, the estuary shows little horizontal changes at the surface level, depending on the period of the year and which of the three main tributaries (Pacuare River, Madre de Dios River or Santa Marta channel) is bringing the majority of the fresh water. Therefore, little horizontal heterogeneity can be assumed in the estuary at a given moment at the surface level. This was another argument for us to analyse the biomarker data taking the lagoon as a unit at the surface level, and assessing the changes in time, according to the pesticides present at each moment.

Regarding the assessment of effects at the biochemical-physiological level in biota exposed to chemical pollution, the biomarker approach was proposed long ago as an appropriate early warning system for the 
assessment of environmental hazards in fish, including the exposure to pesticides (van der Oost et al. 2003). In estuarine ecosystems, biomarker responses might be affected by several factors, like changes in salinity and temperature that can alter the bioavailability of the contaminant substances as well as the metabolism of the organisms (Schipper et al. 2009; Fonseca et al. 2011; Madeira et al. 2013). In temperate regions, the scenario can be different, for example, in sub-arctic species of bivalves and fish, a low seasonal variation in biomarker responses has been observed (Nahrgang et al. 2013) and this has been attributed to the low variation in temperature and salinity of the environment. Meanwhile, tropical estuarine species need to adapt to salinity changes and these mechanisms of adaptation can influence the biotransformation pathways (Schlenk and Lavado 2011) which might also explain seasonal variation in the response of biomarkers in such ecosystems.

Additionally, seasonal variation in biomarker responses in aquatic organisms can also be influenced by the variation in the contamination received by the habitat (Quintaneiro et al. 2006). In this regard, Padmini and Geetha (2009) reported that levels of LPO of fish (Mugil cephalus) inhabiting an estuary exposed to industrial pollution showed a seasonal variation, with values higher in the warmer season. Meanwhile, organisms of the same species, living in a reference site, had no significant seasonal variation.

In the present study, a variation was observed in the response of biomarkers measured in $A$. aeneus throughout the period evaluated. It is known that environmental factors, as well as species-related characteristics, may influence this behaviour (van der Oost et al. 2003) but in our case, conductivity was the environmental parameter with the higher variability during the assessment and still this variation was not correlated to any of the biomarker responses. Further, the observation of a coupled response in biotransformation and oxidative stress related biomarkers, along with the positive correlations found with pesticides and discussed later, suggests that the variation in this case was more influenced by the presence of pesticide residues (as amounts of substances in surface water) than by other environmental factors. In this regard, Stringini-Severo et al. (2020) found that zebrafish embryos exposed to water samples from agricultural areas, had increased GST activities and LPO levels when exposed to the samples with higher amounts of pesticides.

Part of our hypothesis for this work was the presence of OPs and carbamates in LMD would cause ChE inhibition in $A$. aeneus. However, although this group of substances was present in the lagoon water, no significant correlation was found with a reduction in ChE activity in the fish. This could be explained if a previous exposure to ChE-inhibiting compounds occurred and the residual neurological effect was still measurable while the concentrations of the substances already decreased (Zhao and Hwang 2009), but again, the natural variability in the activity of the enzyme should be considered (Fulton and Key 2001). Regarding the observation of significantly lower brain ChE activity at two of the sampling periods and considering a possible previous exposure to ChE-inhibiting pesticides, it should be noted that even environmentally relevant concentrations of such substances can alter the behaviour of fish. This has been observed with chlorpyrifos affecting the locomotion of two tropical fish species (Bonifacio et al. 2017) or ethoprophos, interfering with the escape response of $A$. aeneus (Sandoval-Herrera et al. 2019). Further, Baldwin et al. (2009) estimated that the physiological effects associated with short 
environmental exposure to sub-lethal concentrations of pesticides, especially ChE inhibitors, can affect growth and productivity of salmon.

Even though the OPs and carbamates found in the lagoon did not correlate with the neurotoxic biomarker, the presence of such substances related positively with biotransformation (GST) and oxidative stress signals (LPO). Similar responses have been documented in other fish species. For instance, the exposure to a low concentration of an OP (2-butenoic acid-3-(diethoxy phosphinothionyl) ethyl ester) induced biotransformation and oxidative stress-related responses in tilapia (Rao 2006) and the exposure to a mixture of OP-carbamate induced CAT activity in carps (Khare et al. 2019). As well, similar responses were observed in a characin species exposed to methyl parathion (Amaral-Monteiro et al. 2006). In this regard, some carbamates and OPs, including diazinon, are known to induce oxidative stress in fish (Slaninova et al. 2009) and the biotransformation routes associated with glutathione are involved in the physiological response to these events (Peña-Llopis et al. 2003).

Another insecticide, buprofezin, was positively related to higher levels of LPO. In the case of this substance, it has been demonstrated to induce oxidative stress in mammals ( $\mathrm{Ji}$ et al. 2016). In fish, the exposure of carps to a combination of this insecticide with fipronil has induced oxidative stress and suppression of antioxidant response (Ghazanfar et al. 2018).

The fungicides metalaxyl and azoxystrobin correlated negatively with LPO. Regarding metalaxyl, no studies on its effect on fish LPO were found, however, a test carried out on Tubifex exposed to this fungicide showed that lipid peroxidation was increased, but only after three weeks of exposure (Di et al. 2017). At earlier times, this biomarker was at the level of controls and that delayed effect was related to a saturation of the antioxidant systems. In the case of fish exposed to azoxystrobin, different scenarios have been described: Kumar et al. (2020) found no significant increase in LPO of Danio rerio with a 48hour exposure. In the same species, Han et al. (2016) reported LPO increase during four weeks of exposure to this fungicide. We found two reports that agree with our observation of reduced LPO levels, the first, by Jia et al. (2018) found significantly lower levels of LPO related to a 21-day exposure to azoxystrobin. In the second paper, by Rossi et al. (2020), they observed decreased LPO levels in an Astyanax species, 21 days after an application of a mixture of pesticides. Interestingly, in most of the aforementioned references of works done with worms and fish exposed to these two fungicides, an induction of biotransformation and antioxidant responses was consistently observed. This could explain why, in the context of mixture present in LMD, the presence of such substances at low concentrations and the induction of the antioxidant response can relate to a reduced LPO.

The calculation of IBR allowed the simplification of information and accentuated the differences among samplings. The weight of GST influenced this outcome, as interpreted from the correlation. Considering this integration and relationships, insecticides showed the higher effects observed in fish. Regarding the set of biomarkers used, GST showed the best performance since it was not associated with environmental parameters or with the size or sex of the animals. 
We consider our results relevant regarding the effects of fish being exposed to mixtures of pesticides in a real scenario influenced by agriculture. In a similar study, Teixeira Marins et al. (2020) found comparable biomarker responses in an Astyanax species, with a different context regarding the compounds present in the environment. Further, it is known that the simultaneous exposure to different pollutants can alter the processes of biotransformation and lead to the attenuation or enhancement of the toxicity of specific compounds (Schlenk 2005) which can make confusing the interpretation of biomarkers in field assessments. However, our data shows that some of these responses can be clearly congruent with the environmental exposure to pesticides.

\section{Conclusions}

This work illustrates that the constant pollution of a tropical estuary with pesticide residues caused by runoff from upstream croplands can affect resident biota. The permanent presence of pesticide residues with different biocide actions, even at concentrations that are not expected to cause acute effects, is affecting the physiology and causing oxidative stress on resident fish. The physiological processes related to biotransformation and oxidative stress in $A$. aeneus, respond to the pollution of its habitat with pesticides. The observations in this study are likely found in other areas of Costa Rica and similar ecosystems throughout the tropics. Clearly, the information obtained with the implementation of this approach can add to the protection of such valuable ecosystems.

\section{Declarations}

\section{Funding:}

This work was supported by the "Fondo Institucional de Desarrollo Académico (FIDA)" of Universidad Nacional, project number SIA 0237-15.

\section{Competing interests:}

The authors have no relevant financial or non-financial interests to disclose.

\section{Authors contributions:}

Freylan Mena: Conceptualization, Methodology, Investigation, Formal analysis, Writing - Original draft; Seiling Vargas: Methodology, Investigation, Formal analyses, Writing - Original draft; Meyer GuevaraMora: Validation, Formal analysis, Writing - Original draft; J. Mauro Vargas-Hernández: Validation, Investigation, Writing - Original draft; Clemens Ruepert: Conceptualization, Methodology, Investigation, Formal analysis Supervision, Project administration, Funding acquisition.

\section{Compliance with Ethical Standards:}

Under the legislation applicable during the assessment, this project required permits for collection of the organisms (SINAC-ACLAC-PIME-VS-R-015-2016, SINAC-ACLAC-PI-R-021-2017, R-SINAC-PNI-ACLAC-074- 
2018) and access for genetic or biochemical analyses (R-047-2017-OT-CONAGEBIO).

\section{Consent to Participate:}

Not applicable.

\section{Consent to Publish:}

All authors agree to submit this paper for publication and we all have the consent from our institutional authorities.

\section{Availability of data and materials:}

The authors declare that the results presented in this paper are supported by data, and that such data are available upon request to the authors.

\section{References}

Aebi H (1974) Catalase. In: Bergmayer HU (ed) Methods of enzymatic analysis. Academic, London, pp. 671-684.

Amaral-Monteiro D, Alves de Almeida J, Rantin FT, Kalinin AL (2006) Oxidative stress biomarkers in the freshwater characid fish, Brycon cephalus, exposed to organophosphorus insecticide Folisuper 600 (methyl parathion). Comp Biochem Phys C 143: 141-149. https://doi.org/10.1016/j.cbpc.2006.01.004

Arias-Andrés MJ, Rämö R, Mena F, Ugalde R, Grandas L, Ruepert C, Castillo LE, Van den Brink PJ, Gunnarsson JS (2018) Lower tier toxicity risk assessment of agriculture pesticides detected on the Río Madre de Dios watershed, Costa Rica. Environ Sci Pollut Res Int 25: 13312-13321. https://doi.org/10.1007/s11356-016-7875-7

Baldwin DH, Spromberg JA, Collier TK, Scholz NL (2009) A fish of many scales: extrapolating sublethal pesticide exposures to the productivity of wild salmon populations. Ecol Appl 19, 20042015. https://doi.org/10.1890/08-1891.1

Barbier EB, Hacker SD, Kennedy C, Koch EW, Stier AC, Silliman BR (2011) The value of estuarine and coastal ecosystem services. Ecol Monogr 81: 169-193. https://doi.org/10.1890/10-1510.1

Barletta M, Lima ARA (2019) Systematic Review of Fish Ecology and Anthropogenic Impacts in South American Estuaries: Setting Priorities for Ecosystem Conservation. Front Mar Sci 6:

237. https://doi.org/10.3389/fmars.2019.00237

Bonifacio AF, Ballesteros ML, Bonansea RI, Filippi I, Amé MV, Hued AC (2017) Environmental relevant concentrations of a chlorpyrifos commercial formulation affect two neotropical fish species, Cheirodon 
interruptus and Cnesterodon decemmaculatus. Chemosphere 188: 486-493. https://doi.org/10.1016/j.chemosphere.2017.08.156

Bradford M (1976) A rapid and sensitive method for the quantification of microgram quantities of protein utilizing the principle of protein dye binding. Anal Biochem 72: 248-254.

https://doi.org/10.1006/abio.1976.9999

Brühl CA, Zaller JG (2019) Biodiversity Decline as a Consequence of an Inappropriate Environmental Risk Assessment of Pesticides. Front Environ Sci 7: 177. https://doi.org/10.3389/fenvs.2019.00177.

Bussing W (2002) Freshwater fishes of Costa Rica. 2. ed. 1 Editorial de la Universidad de Costa Rica. San José, Costa Rica, pp. 504.

Colovic MB, Krstic DZ, Lazarevic-Pasti TD, Bondzic AM, Vasic VM (2013) Acetyl cholinesterase inhibitors: pharmacology and toxicology. Curr Neuropharmacol 11: 315-335.

https://doi.org/10.2174/1570159X11311030006

Cuevas N, Martins M, Costa PM (2018) Risk assessment of pesticides in estuaries: a review addressing the persistence of an old problem in complex environments. Ecotoxicology 27: https://doi.org/10081018. 10.1007/s10646-018-1910-z

de Souza Machado AA, Wood CM, Kloas W (2019) Novel Concepts for Novel Entities: Updating Ecotoxicology for a Sustainable Anthropocene. Environ Sci Technol 53: 4680-4682. https://doi.org/10.1021/acs.est.9b02031

Devin S, Burgeot T, Giambérini L, Minguez L, Pain-Devin S (2014) The integrated biomarker response revisited: optimization to avoid misuse. Environ Sci Pollut Res Int 21: 2448-2454. https://doi.org/10.1007/s11356-013-2169-9

Di S, Liu R, Cheng C, Chen L, Zhang W, Tian Z, Liu C, Zhou Z, Diao J (2017) Biomarkers in Tubifex tubifex for the metalaxyl and metalaxyl-M toxicity assessment in artificial sediment. Environ Sci Pollut Res Int 24: 3618-3625. https://doi.org/10.1007/s11356-016-8128-5

Diepens NNJ, Pfennig S, Van den Brink PJ, Gunnarsson JS, Ruepert C, Castillo LE (2014) Effect of pesticides used in banana and pineapple plantations on aquatic ecosystems in Costa Rica. J Environ Biol 35: $73-84$.

Echeverría-Sáenz S, Mena F, Arias-Andrés M, Vargas S, Ruepert C, Van den Brink PJ, Castillo LE, Gunnarsson JS (2018) In situ toxicity and ecological risk assessment of agro-pesticide runoff in the Madre de Dios River in Costa Rica. Environ Sci Pollut Res Int 25: 13270-13282. https://doi.org/10.1007/s11356-016-7817-4

EFSA 2013. Guidance on tiered risk assessment for plant protection products for aquatic organisms in edge-of-field surface waters. EFSA J. 11: 290. https://doi.org/10.2903/j.efsa.2013.3290. 
Elliott M, Quintino V (2007) The Estuarine Quality Paradox, Environmental Homeostasis and the difficulty of detecting anthropogenic stress in naturally stressed areas. Mar Pollut Bull 54: 640-645. https://doi.org/10.1016/j.marpolbul.2007.02.003

Ellman GL, Courtney KD, Andres VJr, Featherstone RM (1961) A new and rapid colorimetric determination of acetylcholinesterase activity. Biochem Pharmacol 7: 88-95. https://doi.org/10.1016/00062952(61)90145-9

EIPaís.cr. 2017. Ecologistas denuncian muerte de peces en Laguna Madre de Dios en barra del Río Pacuare. https://www.elpais.cr/2017/08/16/ecologistas-denuncian-muerte-de-peces-en-laguna-madre-dedios-en-barra-del-rio-pacuare/. Accessed 7-12-2021.

Ferreira M, Moradas-Ferreira P, Reis-Henriques MA (2005) Oxidative stress biomarkers in two resident species, mullet (Mugil cephalus) and flounder (Platichthys flesus), from a polluted site in River Douro Estuary, Portugal. Aquat Toxicol 71: 38-48. https://doi.org/10.1016/j.aquatox.2004.10.009

Floyd EY, Geist JP, Werner I (2008) Acute, sublethal exposure to a pyrethroid insecticide alters behavior, growth, and predation risk in larvae of the fathead minnow (Pimephales promelas). Environ Toxicol Chem 27: 1780-87. https://doi.org/10.1897/07-448.1

Fonseca VF, França S, Vasconcelos RP, Serafim A, Company R, Lopes B, Bebianno MJ, Cabral NH (2011) Short-term variability of multiple biomarker response in fish from estuaries: Influence of environmental dynamics. Mar Environ Res 72: 172-178. https://doi.org/10.1016/j.marenvres.2011.08.001

Fulton MH, Key PB (2001) Acetylcholinesterase inhibition in estuarine fish and invertebrates as an indicator of organophosphorus insecticide exposure and effects. Environ Toxicol Chem 20: 37-45. https://doi.org/10.1897/1551-5028(2001)020<0037:aiiefa>2.0.co;2

Ghazanfar M, Shahid S, Qureshi IZ (2018) Vitamin C attenuates biochemical and genotoxic damage in common carp (Cyprinus carpio) upon joint exposure to combined toxic doses of fipronil and buprofezin insecticides. Aquat Toxicol 196: 43-52. https://doi.org/10.1016/j.aquatox.2017.12.015

Guilhermino L, Lopes M, Carvalho A, Soares A (1996) Inhibition of acetylcholinesterase activity as effect criterion in acute tests with juvenile Daphnia magna. Chemosphere 32: 727-738.

https://doi.org/10.1016/0045-6535(95)00360-6

Habig WH, Pabst MJ, Jakoby WB (1974) Glutathione S-transferases. The first enzymatic step in mercapturic acid formation. Biol Chem 249: 7130-7139. https://doi.org/10.1016/S0021-9258(19)420838

Han Y, Liu T, Wang J, Wang J, Zhang C, Zhu L (2016) Genotoxicity and oxidative stress induced by the fungicide azoxystrobin in zebrafish (Danio rerio) livers. Pestic Biochem Phys 133: 13-19. https://doi.org/10.1016/j.pestbp.2016.03.011 
Harrell FE Jr., with contributions from Charles Dupont and many others (2020) Hmisc: Harrell Miscellaneous. R package version 4.4-0. https://CRAN.R-project.org/package=Hmisc.

IMN (2021) Instituto Meteorológico Nacional. Clima en Costa Rica, Vertiente del Caribe. https://www.imn.ac.cr/documents/10179/31165/VertienteCaribe.pdf/acd336b0-9c69-444a-9316f168945c9a6d. Accessed 7-12-2021.

Jennerjahn TC, Mitchell SB (2013) Pressures, stresses, shocks and trends in estuarine ecosystems. An introduction and synthesis. Estuar Coast Shelf S 130: 1-8. https://doi.org/10.1016/j.ecss.2013.07.008

Ji X, Ku T, Zhu N, Ning X, Wei W, Li G, Sang N (2016) Potential hepatic toxicity of buprofezin at sublethal concentrations: ROS-mediated conversion of energy metabolism. J Hazard Mater 320: 176-186. https://doi.org/10.1016/j.jhazmat.2016.08.027

Jia W, Mao L, Zhang L, Zhang Y, Jiang H (2018) Effects of two strobilurins (azoxystrobin and picoxystrobin) on embryonic development and enzyme activities in juveniles and adult fish livers of zebrafish (Danio rerio). Chemosphere 207: 573-580. https://doi.org/10.1016/j.chemosphere.2018.05.138

Karmakar S, Patra K, Jana S, Mandal DP, Bhattacharjee S (2016) Exposure to environmentally relevant concentrations of malathion induces significant cellular, biochemical and histological alterations in Labeo rohita. Pestic Biochem Phys 126: 49-57. https://doi.org/10.1016/j.pestbp.2015.07.006

Khare A, Chhawani, N, Kumari K (2019) Glutathione Reductase and Catalase as Potential Biomarkers for Synergistic intoxication of Pesticides in fish. Biomarkers 24: 666-676.

doi.org/10.1080/1354750X.2019.1651902.

Kumar N, Willis A, Satbhai K, Ramalingam L, Schmitt C, Moustaid-Moussa N, Crago J (2020) Developmental toxicity in embryo-larval zebrafish (Danio rerio) exposed to strobilurin fungicides (azoxystrobin and pyraclostrobin). Chemosphere 241, 124980.

https://doi.org/10.1016/j.chemosphere.2019.124980

La Gaceta (2007) Reglamento sobre Registro, Uso y Control de Plaguicidas Sintéticos Formulados, Ingrediente Activo Grado Técnico, Coadyuvantes y Sustancias Afines de Uso Agrícola № 33495.

La Nación (2009) Vecinos denuncian matanza masiva de peces en Matina.

http://wvw.nacion.com/In_ee/2009/febrero/25/pais1886110.html. Accessed 30-04-2020

Lewis KA, Tzilivakis J, Warner D, Green A (2016) An international database for pesticide risk assessments and management. Hum Ecol Risk Assess 22: 1050-1064.

https://doi.org/10.1080/10807039.2015.1133242

Madeira D, Narciso L, Cabral HN, Vinagre C, Diniz MS (2013) Influence of temperature in thermal and oxidative stress responses in estuarine fish. Comp Biochem Phys A 166: 237-243.

https://doi.org/10.1016/j.cbpa.2013.06.008

Page 17/22 
Martínez-Álvarez RM, Morales AE, Sanz A (2005) Antioxidant defenses in fish: Biotic and abiotic factors. Rev Fish Biol Fisher 15: 75-88. https://doi.org/10.1007/s11160-005-7846-4

Mena F, Azzopardi M, Pffenig S, Ruepert C, Tedengren M, Castillo LE, Gunnarsson JS (2014) Use of cholinesterase activity as a biomarker of pesticide exposure used on Costa Rican banana plantations in the native tropical fish (Günther, 1860) Astyanax aeneus. J Environ Biol 35: 35-42.

Monserrat JM, Martínez PE, Geracitano LA, Lund Amado L, Martinez C, Martins G, Pinho GLL, Soares Chaves I, Ferreira-Cravo M, Ventura-Lima J, Bianchini A (2007) Pollution biomarkers in estuarine animals: Critical review and new perspectives. Comp Biochem Phys C. 146: 221-

234. https://doi.org/10.1016/j.cbpc.2006.08.012

Nahrgang J, Brooks SJ, Evenset A, Camus L, Jonsson M, Smith TJ, Lukina J, Frantzen M, Giarratano E, Renaud PE (2013) Seasonal variation in biomarkers in blue mussel (Mytilus edulis), Icelandic scallop (Chlamys islandica) and Atlantic cod (Gadus morhua)-Implications for environmental monitoring in the Barents Sea. Aquat Toxicol 127: 21-35. https://doi.org/10.1016/j.aquatox.2012.01.009

Narra MR, Rajender K, Reddy RR, Murty US, Begum G (2017) Insecticides induced stress response and recuperation in fish: Biomarkers in blood and tissues related to oxidative damage. Chemosphere 168: 350-357. https://doi.org/10.1016/j.chemosphere.2016.10.066

Oakes FD, Van Der Kraak VD (2003) Utility of TBARS assay in detecting oxidative stress in white sucker (Catostomus commersoni) populations exposed to pulp mill effluent. Aquat Toxicol 63: 447463. https://doi.org/10.1016/s0166-445x(02)00204-7

Oksanen J (2011) Multivariate analysis of ecological communities in R: vegan tutorial. R package version, 1(7), 1-43

Padmini E, Geetha BV (2009) Impact of season on liver mitochondrial oxidative stress and the expression of HSP70 in grey mullets from contaminated estuary. Ecotoxicology 18: 304-311. https://doi.org/10.1007/s10646-008-0282-1

Peña-Llopis S, Ferrando MD, Peña JB (2003) Fish tolerance to organophosphate-induced oxidative stress is dependent on the glutathione metabolism and enhanced by $\mathrm{N}$-acetylcysteine. Aquat Toxicol 65: 337360. https://doi.org/10.1016/s0166-445x(03)00148-6

Polidoro BA, Morra MJ (2016) An ecological risk assessment of pesticides and fish kills in the Sixaola watershed, Costa Rica. Environ Sci Pollut Res Int 23: 5983-5991. https://doi.org/10.1007/s11356-0166144-0

Quintaneiro C, Monteiro M, Pastorinho R, Soares AMVM, Nogueira AJA, Morgado F, Guilhermino L (2006) Environmental pollution and natural populations: A biomarkers case study from the lberian Atlantic coast. Mar Pollut Bull 52: 1406-1413. https://doi.org/10.1016/j.marpolbul.2006.04.002 
R Core Team (2019) R: A language and environment for statistical computing. R Foundation for Statistical Computing, Vienna, Austria. URL https://www.R-project.org/.

Rämö RA, van den Brink PJ, Ruepert C, Castillo LE, Gunnarsson JS (2018) Environmental risk assessment of pesticides in the River Madre de Dios, Costa Rica using PERPEST, SSD, and msPAF models. Environ Sci Pollut Res Int 25: 13254-13269. https://doi.org/10.1007/s11356-016-7375-9

Rao JV (2006) Toxic eVects of novel organophosphorus insecticide (RPR-V) on certain biochemical parameters of euryhaline Wsh, Oreochromis mossambicus. Pestic Biochem Phys 86: 78-

84. https://doi.org/10.1016/j.pestbp.2006.01.008

Rossi AS, Fantón N, Michlig MP, Repetti MR, Cazenave J (2020) Fish inhabiting rice fields: Bioaccumulation, oxidative stress and neurotoxic effects after pesticides application. Ecol Indic 113: 106186. https://doi.org/10.1016/j.ecolind.2020.106186

Sandoval-Herrera NI, Mena-Torres F, Espinoza M, Romero A (2019) Neurotoxicity of organophosphate pesticides could reduce the ability of fish to escape predation under low doses of exposure. Sci Rep-UK 9(1): 10530. https://doi.org/10.1038/s41598-019-46804-6.

Schipper CA, Lahr J, van den Brink PJ, George SG, Hansen PD, da Silva de Assis HC, van der Oost R, Thain JE, Livingstone D, Mitchelmore C, van Schooten FJ, Ariese F, Murk Aj, Grinwis GCM, Klamer H, Kater BJ, Postma JF, van der Werf B, Vethaak AD (2009) A retrospective analysis to explore the applicability of fish biomarkers and sediment bioassays along contaminated salinity transects. ICES J Mar Sci 66: 20892105. https://doi.org/10.1093/icesjms/fsp194

Schlenk D (2005) Pesticide biotransformation in fish. In: Mommsen, TP., Moon, TW. (Eds.), Biochemistry and molecular biology of fishes, vol. 6. Elsevier B.V.

Schlenk D, Celander M, Gallagher EP, George S, James M, Kullman SW, van der Hursk P, Willett K (2008) Biotransformation in fishes. In: Di Giulio, RT., Hinton, DE. (Eds.), The Toxicology of Fishes. CRC Press, Boca Raton, FL, pp. 153-234.

Schlenk D, Lavado R (2011) Impacts of climate change on hypersaline conditions of estuaries and xenobiotic toxicity. Aquat Toxicol 105S: 78- 82. https://doi.org/10.1016/j.aquatox.2011.06.023

Schreiner VC, Szöcs E, Bhowmik AK, Vijver MG, Schäfer RB (2016) Pesticide mixtures in streams of several European countries and the USA. Sci Total Environ 573: 680-689.

https://doi.org/10.1016/j.scitotenv.2016.08.163

Slaninova A, Smutna M, Modra H, Svobodova Z (2009) A review: Oxidative stress in fish induced by pesticides. Neuroendocrinol Lett 30: 2-12.

Stringini-Severo E, Teixeira-Marins A, Cerezer C, Costa D, Nunes M, Damian-Prestes O, Zanella R, LuciaLoro V (2020) Ecological risk of pesticide contamination in a Brazilian river located near a rural area: A 
study of biomarkers using zebrafish embryos. Ecotox. Environ. Safe. 190, 110071. https://doi.org/10.1016/j.ecoenv.2019.110071.

Teixeira-Marins A, Stringini-Severo E, Wesz-Leitemperger J, Cerezer C, Elwanger-Muller T, Dorneles-Costa M, Henrique-Weimer G, Grubel-Bandeira NM, Damian-Prestes O, Zanella R, Lucia-Loro V

(2020) Assessment of River Water Quality in an Agricultural Region of Brazil Using Biomarkers in a Native Neotropical Fish, Astyanax spp. (Characidae). B Environ Contam Tox 104: 575-

581. https://doi.org/10.1007/s00128-020-02821-0

Toft JD, Munsch SH, Cordell JR, Siitari K, Hare VC, Holycross BM, DeBruyckere LA, Greene CM, Hughes BB (2018). Impact of multiple stressors on juvenile fish in estuaries of the northeast Pacific. Glob Change Biol 24: 2008-2020. https://doi.org/10.1111/gcb.14055

Topping CJ, Aldrich A, Berny P (2020) Overhaul environmental risk assessment for pesticides. Science 367: 360-363. https://doi.org/10.1126/science.aay1144

van der Oost R, Beyer J, Vermeulen NPE (2003) Fish bioaccumulation and biomarkers in environmental risk assessment: a review. Environ Toxicol Phar 13: 57-149. https://doi.org/10.1016/s13826689(02)00126-6

Warwick RM, Tweedley JR, Potter IC (2018) Microtidal estuaries warrant special management measures that recognisetheir critical vulnerability to pollution and climate change. Mar Pollut Bull 135: 41-46. https://doi.org/10.1016/j.marpolbul.2018.06.062

Zhao X, Hwang H (2009) A study of the degradation of the degradation of organophosphorus pesticides in river waters and the identification of their degradation products with chromatography coupled to mass spectrometry. Arch Environ Contam Toxicol 56: 646-53. https://doi.org/10.1007/s00244-008-9220-8

\section{Figures}




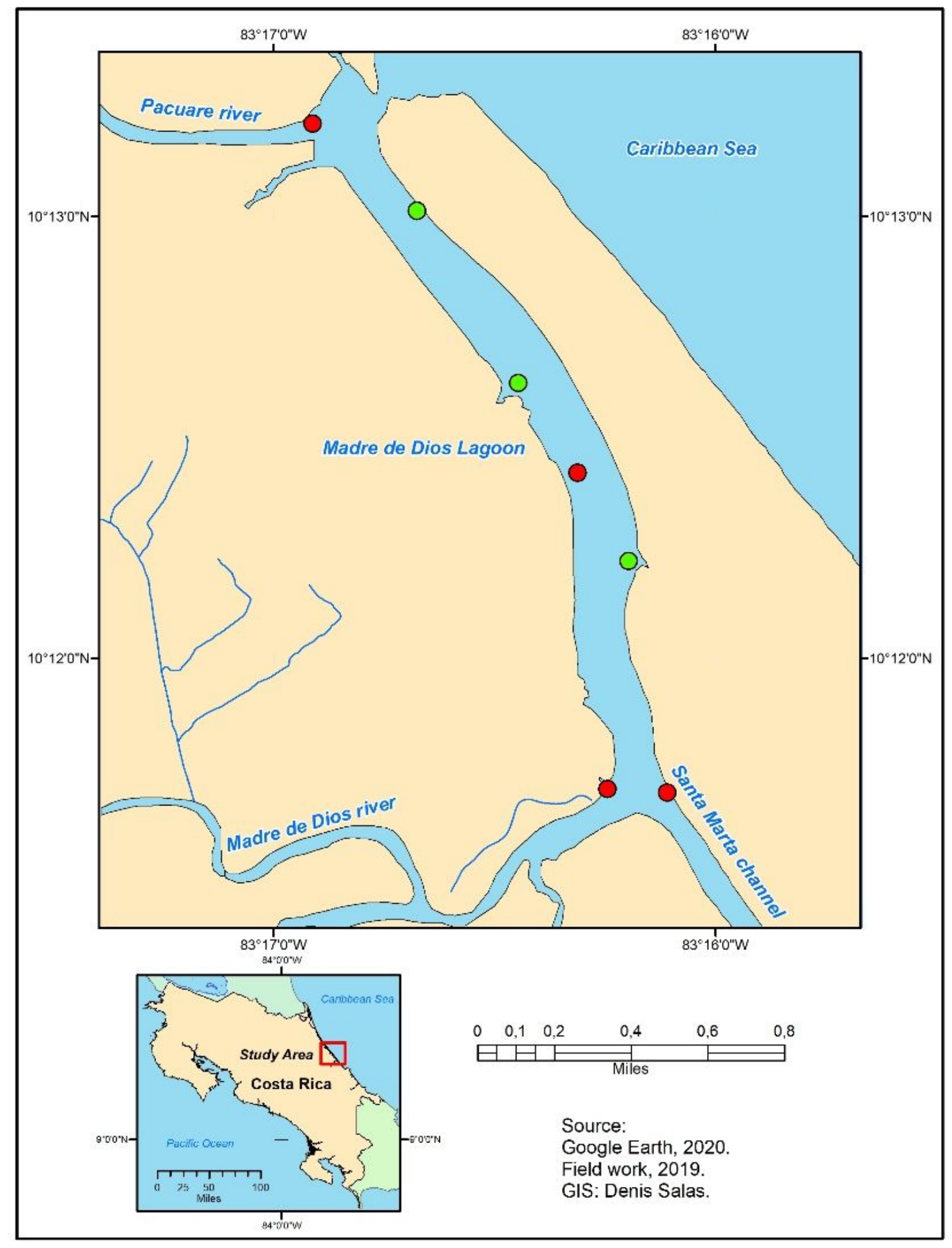

\section{Figure 1}

LMD, indicating points where fish and water samples were collected. A. aeneus were collected at all points while water grab samples were collected only at the red points 


\section{Figure 2}

Biomarkers measured in $A$. aeneus collected at LMD throughout seven campaigns, indicated as monthyear. Statistical differences $(p \leq 0.05)$ in the biomarkers measured among sampling moments are indicated with different letters. Bars indicate standard error. In the case of CAT, data is presented by sex.
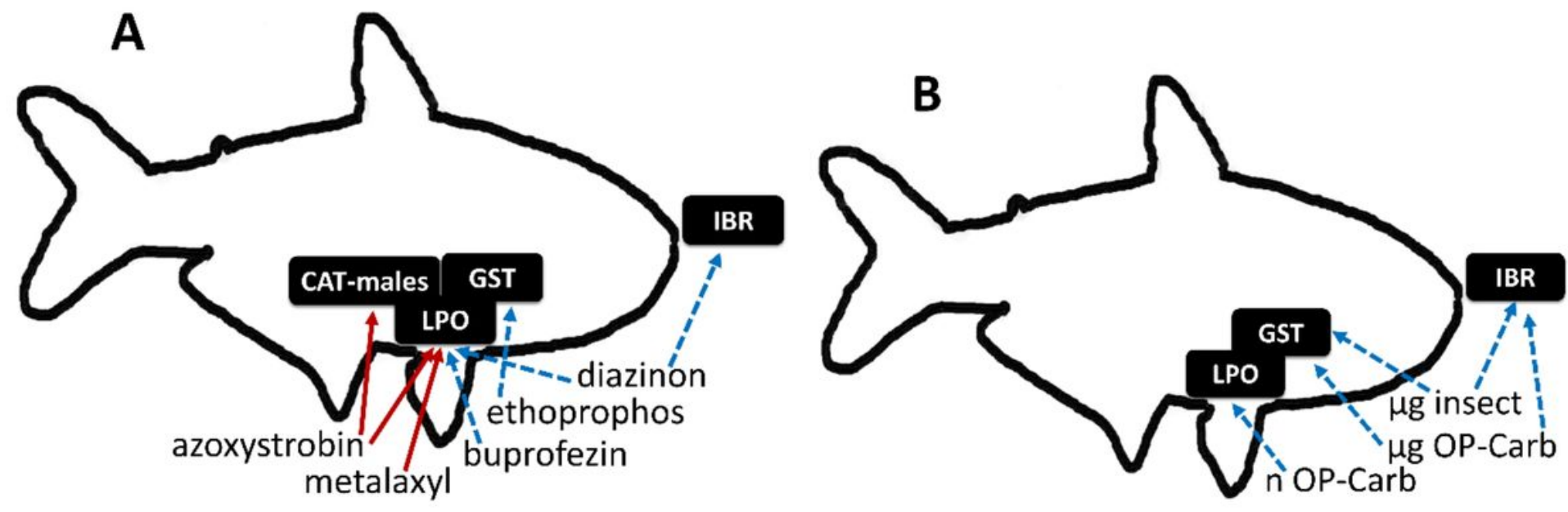

Figure 3

Significant correlations of biomarkers measured in A. aeneus with peaks of pesticide residues detected in LMD. Schemes summarize the significant $(\mathrm{p} \leq 0.05)$ correlations between specific individual pesticides $(A)$, or groups of pesticides $(B)$, and biomarker responses. Positive correlations are indicated with blue interrupted arrow and negative correlations with red continuous arrows

\section{Supplementary Files}

This is a list of supplementary files associated with this preprint. Click to download.

- Supplementarylnformation.pdf 